\title{
Cultivating Settler Colonial Space in Korea: Public Works and the Urban Environment under Japanese Rule
}

Tristan R. Grunow*

Settler colonialism destroys to replace.

- Patrick Wolfe, $2006^{1}$

It is said that if we are to build a new age here in Korea, then the present must be destroyed. But even that destruction is done for the purpose of creation.

- Kuroita Katsumi, $1922^{2}$

* The author is Associate Research Scholar in the Council on East Asian Studies at Yale University. Recent publications include "Paving Power: Western Urban Planning and Imperial Space from the Streets of Meiji Tokyo to Colonial Seoul," published in the Journal of Urban History in 2016, and "Pebbles of Progress: Streets and Urban Modernity in Early Meiji Tokyo" in Japan Forum in 2019. He would like to thank the anonymous peer reviewers for their generous and helpful feedback on an earlier draft of this article.

** Naming conventions for all Korean and Japanese names in the text, footnotes, and bibliography follow IJKH guidelines.

1 Patrick Wolfe, "Settler colonialism and the elimination of the native," Journal of Genocide Research 8, no. 4 (December 2006): 388.

2 Kuroita Katsumi, "Bunka to Kenchiku," Chōsen to Kenchiku 1, no. 2 (February 1922): 3. 
Japanese colonial rule in Korea was built as much on the domination and exploitation of the Korean landscape as it was on the harsh control of the Korean population. By one estimation, Japan expended $\$ 8$ billion USD on public works programs over the 35 years it occupied Korea between the years 1910-1945. ${ }^{3}$ In rural areas, Japanese colonizers laid railways, improved rural highways, built dams, and constructed ports in order to spur industrial development, facilitate commerce, and promote trade. Better communications would also accelerate troop movements in times of emergency. In urban areas, such as Seoul, Pusan, and Pyongyang, Japanese engineers paved streets, installed sidewalks, buried water and sewer pipes, and erected Western-style buildings in order to sanitize the city, improve everyday life, and construct urban spaces designed to impress Korean residents and encourage them to acquiesce and assimilate to Japanese rule.

All these projects required immense manipulation of Korean natural and built environments. Massive amounts of earth had to be dynamited, cleared, and removed for mountainside cuttings, tunnels, bridges, and embankments to provide straight and level passages and rights-of-way for road and rail. Enormous amounts of stone and gravel had to be quarried for rail bed ballast and street surface pavements. Vast stores of timber, granite, marble, and brick had to be harvested for the construction of monumental Western-style structures. Railway track beds themselves were formed of earth subgrade and stone ballast, not to mention the wooden railway ties and steel rails laid on top to form the tracks. In this way, the imposition of Japanese colonial rule was inscribed into even the landscapes and spaces of the peninsula.

Japanese colonial officials publicly justified and touted public works projects in the language of development, measuring the success of Japanese colonial rule in kilometers of rails laid, roads improved, and tele-

3 Lee Hong-Yung, "Introduction: A Critique of 'Colonial Modernity'," in Colonial Rule and Social Change in Korea, 1910-1945, ed. Lee Hong-Yung, et al. (Seattle: University of Washington Press, 2013), 11. 
graph wires strung, while boasting indices of increased agricultural output, economic activity, and foreign trade in so-called Annual Reports on Reforms and Progress in Chosen (Korea) [sic] published around the English-speaking world starting in 1907 and continuing until WWII. Yet, for Japanese settlers, public works projects in Korea were not simply about extracting resources, boosting productivity, expediting mobility, or advancing assimilationist policies. Instead, for Japanese colonizers, public works projects were mechanisms for reshaping Korean landscapes in the name of cultivating Japanese claims to ownership of Korean territory and displacing Korean inhabitants. In this regard, colonial public works reified Japanese views of the Korean natural environment as a malleable space to be claimed, ordered, and exploited for the benefit of the Japanese metropole and resident settler population. In other words, public works projects were tools for claiming and constructing Japanese settler colonial spaces in Korea.

In recent years, scholars of East Asian history have increasingly debated whether Japanese expansion and imperialism in the late-19 ${ }^{\text {th }}$ century can be considered settler colonialism, defined here as a process through which an exogenous settler population invades a new territory, and then erects socioeconomic, political, and racial structures designed to eliminate native inhabitants via violence or assimilation as a way to gain access to, and sustain settler exploitation of, native territory. ${ }^{4}$ As Penelope Edmonds points out, the "central dynamic" of setter colonialism was "supersession, that is, the displacement of Indigenous peoples and their replacement with settlers." 5 Or in Patrick Wolfe's pithy phrasing: "settler

4 This broad definition is drawn from two sources: Wolfe, "Settler colonialism and the elimination of the native," 387-390; and Lorenzo Veracini, "Settler Colonialism': Career of a Concept," The Journal of Imperial and Commonwealth History 41, no. 2 (2013): 313-314.

5 Penelope Edmonds, “Unpacking Settler Colonialism's Urban Strategies: Indigenous Peoples in Victoria, British Columbia, and the Transition to a Settler-Colonial City," Urban History Review 38, no. 2 (March 2010): 5. 
colonizers come to stay: invasion is a structure not an event." ${ }^{\text {" In this }}$ regard, it is important to note that settler colonialism is not simply the migration of farmers or merchants from one territory to another in search of economic opportunity, especially when they do not intend to stay. Rather, it refers to the entirety of the process whereby settlers eliminate and replace natives by introducing new states, societies, and structures of power. "Everyone is a settler," Lorenzo Veracini clarifies, "if they are part of a collective and sovereign displacement that moves to stay, that moves to establish a permanent homeland by way of displacement." ${ }^{\text {" It }}$ also differs from other forms of colonialism whose goal was metropolitan access to markets, exploitation of labor or natural resources, or control of territory. There is little question that the Japanese occupation of the northern island of Hokkaidō and other peripheral territories such as Karafuto, the Kurile islands, and Okinawa starting in 1869, along with the subsequent displacement and ethnic negation of the Indigenous Ainu and Okinawan peoples, were acts of settler colonialism. ${ }^{8}$ Whether or not Japanese expansion elsewhere in East Asia constituted settler colonialism, on the other hand, is more debated, largely because of the relatively small

6 Wolfe, "Settler colonialism and the elimination of the native," 388.

7 Lorenzo Veracini, "Settler colonialism as a distinct mode of domination," in The Routledge Handbook of the History of Settler Colonialism, ed. Edward Cavanaugh and Lorenzo Veracini (New York: Routledge, 2016), 4.

8 On settler colonialism in Hokkaidō, see: David Howell, "Making 'Useful Citizens' of Ainu Subjects in Early Twentieth-Century Japan," The Journal of Asian Studies 63, no. 1 (February 2004): 5-29; Michele M. Mason, Dominant Narratives of Colonial Hokkaido and Imperial Japan: Envisioning the Periphery and the Modern Nation-State (New York: Palgrave Macmillan, 2012); and Tristan R. Grunow, et al., "Hokkaidō 150: settler colonialism and Indigeneity in modern Japan and beyond," Critical Asian Studies 51, no. 4 (December 2019): 597-636. On Okinawa, see Alan S. Christy, "The Making of Imperial Subjects in Okinawa," positions 1, no. 3 (1993): 607-639. See also Eiji Oguma, The Boundaries of "the Japanese” (Melbourne: Trans Pacific Press, 2014), translated from "Nihonjin” no Kyōkai: Okinawa, Ainu, Taiwan, Chōsen Shokuminchi Shihai kara Fukki Undō made (Tokyo: Shin'yōsha, 1998). 
numbers of Japanese who emigrated overseas and the short lifespan of the overseas Japanese empire. ${ }^{9}$

Japanese colonial rule in Korea, especially, seems to defy characterization as a case of settler colonialism at first glance. As Hyung-Gu Lynn points out, Japanese residents never became a dominant majority in the peninsula, never even surpassing $3 \%$ of the total population, nor were Koreans removed from their lands or placed on reservations. ${ }^{10}$ Still, Japan's forced annexation of Korea in 1910 announced its long-term intentions to stay, and the policies Japanese colonizers enacted to suppress outward representation of Korean identity call to mind similar so-called "Indian policies" enacted by the United States, among other settler societies around the globe, in the name of assimilation. Most importantly, Japanese colonial officials and settlers arriving in Korea brought with them their own ideas of civilization and space, and then not only imposed those ideas onto native Korean soil but also erected a number of structures to displace Korean inhabitants and make room for Japanese settlers. As Tracey Banivanua Mar and Penelope Edmonds remind us, "Settlers, in the end, tended not to emigrate to assimilate into Indigenous societies, but rather emigrated to replace them." "To be sure, Japanese colonizers were not monolithic; the colonial state and expatriate residents in Korea were

9 See: Hyung-Gu Lynn, "Malthusian Dreams, Colonial Imaginary: The Oriental Development Company and Japanese Emigration to Korea," in Settler Colonialism in the Twentieth Century, ed. Caroline Elkins and Susan Pedersen (New York: Routledge, 2005), 25-40. For other work viewing Japanese expansion through the lens of settler colonialism, see: Sidney Xu Lu, The Making of Japanese Settler Colonialism: Malthusianism and Trans-Pacific Migration, 1868-1961 (Cambridge: Cambridge University Press, 2019), and Eiichiro Azuma, In Search of Our Frontier: Japanese America and Settler Colonialism in the Construction of Japan's Borderless Empire (Berkeley: University of California Press, 2019).

10 Lynn, "Malthusian Dreams, Colonial Imaginary," 25.

11 Tracey Banivanua Mar and Penelope Edmonds, "Introduction: Making Space in Settler Colonies," in Making Settler Colonial Space: Perspectives on Race, Place and Identity, ed. Tracey Banivanua Mar and Penelope Edmonds (New York: Palgrave Macmillan, 2010), 2. 
not a unified bloc that always saw eye to eye, as Jun Uchida and Kim Baek-Yung have persuasively documented. ${ }^{12}$ Nonetheless, even on those occasions when they disagreed about best practices or the direction of policy, they still shared the final goal of advancing Japanese interests and securing settler access to space, thereby displacing and replacing Koreans in the process. Settler colonialism is therefore an instructive analytic framework for reviewing Japanese colonial intrusions into Korean society and space, particularly Japanese attempts to reshape Korean environments.

Settler colonialism offers provocative new ways to understand the relationship between colonialism, space, the environment, race, and power. ${ }^{13}$ Scholars of imperialism have long recognized the roles of architecture, urban planning, and infrastructural development in mediating colonial power. ${ }^{14}$ Separately, over the last several decades since the publication of Alfred Crosby's 1986 Ecological Imperialism, scholars of environmental history have begun to map the environmental and ecological factors propelling European imperialist expansion in the $19^{\text {th }}$ century, as well the environmental impacts arising from the extraction of colonial resources to fuel capitalist growth. ${ }^{15}$ Subsequent work has highlighted how both state

12 Jun Uchida, Brokers of Empire: Japanese Settler Colonialism in Korea, 1876-1945 (Cambridge: Harvard University Asia Center, 2011); and Kim Baek-Yung, "Ruptures and Conflicts in the Colonial Power Bloc: The Great Keijo Plan of the 1920s," Korea Journal 48 (August 2008): 10-40.

13 See especially Tracey Banivanua Mar and Penelope Edmonds, ed., Making Settler Colonial Space: Perspectives on Race, Place and Identity (New York: Palgrave Macmillan, 2010)

14 See, for example: Anthony D. King, Colonial Urban Development: Culture, Social Power, and Environment (Boston: Routledge, 1976); Gwendolyn Wright, The Politics of Design in French Colonial Urbanism (Chicago: The University of Chicago Press, 1991); Brenda S.A. Yeoh, Contesting Space: Power Relations and the Urban Built Environment in Colonial Singapore (New York: Oxford University Press, 1996); Ambe J. Njoh, Planning Power: Town Planning and Social Control in Colonial Africa (New York: UCL, 2006).

15 Alfred Crosby, Ecological Imperialism: The Biological Expansion of Europe, 9001900 (Cambridge University Press, 1986); William Beinart \& Lotte Hughes, ed., 
and local power reshapes natural environments towards individual goals, whether political, economic, or cultural. ${ }^{16}$ More recently, scholars have applied the tools of settler colonial studies to environmental history, as Clint Carroll writes, to "help make sense of environmental practices and politics - and their resulting effects on people, other-than-human animals, and landscapes." 17

Rethinking urban environmental history through settler colonial studies reminds scholars to be mindful of how settler societies reshaped colonial urban spaces not only to project imperial power, culture, and rule, but to dispossess, displace, alienate, and eliminate native peoples and their cultures. ${ }^{18}$ As Lorenzo Veracini writes, settler colonialism is a "violent act against geography: settler colonialism turns someone else's place into

Environment and Empire (Oxford University Press, 2007); Peder Anker, Imperial Ecology: Environmental Order in the British Empire 1895-1945 (Cambridge: Harvard University Press, 2001); Richard P. Tucker, Insatiable Appetite: The United States and the Ecological Degradation of the Tropical World (Berkeley: University of California Press, 2000).

16 Arun Agrawal, Environmentality: Technologies of Government and the Making of Subjects (Durham, NC: Duke University Press, 2005); Karen M. O’Neill, Rivers by Design: State Power and the Origins of US Flood Control (Durham, NC: Duke University Press, 2006); Tania Murray Li, The Will to Improve: Governmentality, Development, and the Practice of Politics (Durham, NC: Duke University Press, 2007); Cynthia Radding, Landscapes of Power and Identity: Comparative Histories in the Sonoran Desert and the Forests of Amazonia from Colony to Republic (Durham, NC: Duke University Press, 2005); Jayeeta Sharma, Empire's Garden: Assam and the Making of India (Durham, NC: Duke University Press, 2011).

17 Clint Carroll, "Commentary: The Environmental Anthropology of Settler Colonialism, Part II," Engagement. https://aesengagement.wordpress.com/2017/05/16/com mentary-the-environmental-anthropology-of-settler-colonialism-part-ii/.

18 For urban settler colonialism, see David Hugill, "What is a settler-colonial city?" Geography Compass 11, no. 5 (May 2017); Libby Porter and Oren Yiftachel, "Urbanizing Settler-Colonial Studies: Introduction to the Special Issue," Settler Colonial Studies 9, no. 2 (2019): 177-186; and Julie Tomiak, "Contesting the Settler City: Indigenous Self-Determination, New Urban Reserves, and the Neoliberalization of Colonialism," Antipode 49, no. 4 (2017): 928-945. 
space and then into place again." 19 Without question, replacement of native peoples and cultures with settler forms entailed tremendous alteration of physical landscapes in the process. In the words of Patrick Wolfe, "settler colonialism destroys to replace." 20 That is, settlers destroyed native societies, along with their vernacular forms, and in their place reconstructed settler colonial spaces where natives were seen as out of place. "The impact of settler colonialism is starkly visible in the landscapes it produces," Tracey Banivanua Mar and Penelope Edmonds note:

The symmetrically surveyed divisions of land; fences, roads, power lines, dams and mines; the vast mono-cultural expanses of single-cropped fields; carved and preserved national forest, and marine and wilderness parks; the expansive and gridded cities; and the socially coded areas of human habitation and trespass that are bordered, policed and defended. Land and the organised spaces on it, in other words, narrate the stories of colonisation. ${ }^{21}$

As part of the strategy of "destroying to replace," settler colonial cities differ from traditional "colonial cities" built to facilitate the exploitation and extraction of colonial resources for the economic benefit of the metropole. As David Hugill argues, the "colonial city" was a "'historic' form of spatial production that is typified by a highly segregated urban organization and designed to facilitate the smooth flow of human and resource surpluses from a colonized 'periphery' to a metropolitan "core."'22 Production of settler colonial cities, on the other hand, was "animated by a more permanent ambition to settle and permanently transform the colonized territory." "The 'settler-colonial city' differs fundamentally from the "colonial city," Hugill elaborates:

19 Veracini, "Settler colonialism as a distinct mode of domination," 5.

20 Wolfe, "Settler colonialism and the elimination of the native," 388.

21 Mar and Edmonds, "Introduction," 2.

22 Hugill, "What is a settler-colonial city?," 4. 
(B)ecause (a) its accumulation strategies are primarily oriented around the enrichment of settler constituencies, rather than farflung metropolitan sponsors, (b) the colonial relation remains a central and enduring element of its contemporary life, albeit in dynamic and frequently recomposed forms, (c) and Indigenous peoples themselves have more often been excluded from, rather than exploited in, its core economic activities. ${ }^{23}$

To be sure, two important features of the settler colonial city that distinguish it from the colonial city are that the settler population is demographically majoritarian, and that no process of decolonization has occurred, meaning settler presence and domination continues into the present. These two points alone might be enough to call into question the applicability of settler colonialism to the case of Japanese rule in Korea. Yet, as Hugill admits, settler spaces operate as sites where the interests of "“foreign invaders' are made manifest in the materiality of bricks and mortar," and where settlers have as their "primary interest" the "eventual clearing of the expropriated territory for settler use and the incorporation of that territory into the regulatory ambit of settler institutions of governance." ${ }^{24}$ Questioning whether or not the Japanese colonial elite constituted a demographic majority should not distract from investigation of to whose benefit, at whose expense, and to what end Japanese colonial rulers enacted public works programs. Nor should the rapid defeat and collapse of the empire in 1945 give the false impression that Japanese colonizers did not intend to remain. For these reasons, it is worth inquiring what new perspectives the settler colonial framework can offer on the aims of Japanese colonial urban policies.

This article makes a case for reviewing Japanese rule in Korea through the lens of settler colonialism, arguing that Japanese colonial officials, civil engineers, and settlers designed settler colonial spaces in Seoul with

23 Hugill, "What is a settler-colonial city?," 6-7.

24 Hugill, "What is a settler-colonial city?," 6. 
the goal of displacing native Koreans. Previous work on spatial politics in colonial Seoul, especially by Todd Henry, has mapped the everyday tactics Korean residents used to rearticulate and contest Japanese assimilation efforts, along with highlighting convergences between metropolitan and colonial discourses on urban space and hygiene. ${ }^{25}$ Kim Baek-Yung has also showed how Korean residents' spatial practice challenged Japanese efforts to enforce discipline through urban space. ${ }^{26}$ A larger body of research has reviewed Japanese urban improvement programs from the perspective of planning and architectural history to document Japanese alterations of the Seoul urban fabric in the name of justifying Japanese colonialism, the construction of "colonial modernity" in the city, and the development of capitalism. ${ }^{27}$ At the same time, a number of scholars including Hyung-min Pai, Kyu-Mok Lee, and Hong Kal to name just a few, have documented the cultural impacts of Japanese urban redevelopment

25 Todd A. Henry, Assimilating Seoul: Japanese Rule and the Politics of Public Space in Colonial Korea, 1910-1945 (Berkeley: University of California Press, 2014); Todd A. Henry, "Sanitizing Empire: Japanese Articulations of Korean Otherness and the Construction of Early Colonial Seoul, 1905-1919," The Journal of Asian Studies 64, no. 3 (August 2005): 649-675; and Todd A. Henry, "Respatializing Chosŏn's Royal Capital: The Politics of Japanese Urban Reforms in Early Colonial Seoul, 1905-1919," in Sitings: Critical Approaches to Korean Geography, ed. Timothy Tangherlini and Sallie Yea (Honolulu: University of Hawai'i Press, 2007), 15-38.

26 Kim Baek-Yung, "Shokuminchi toshi Keijō no hiroba to roji," in Shokuminchi Chōsen to Teikoku Nihon: Minzoku, Toshi, Bunka, ed. Suh Johng Wan and Masuo Shinichirō (Tokyo: Bensei Shuppan, 2010), 21-31.

27 See especially Sohn Chŏng-Mok, "Colonial City Planning and Its Legacy," in Seoul, Twentieth Century: Growth \& Change of the Last 100 Years, ed. Kim Kwang-Joong (Seoul: Seoul Development Institute, 2003), 489-542; and Jeong Won-Sik, "The Urban Development Politics of Seoul as a Colonial City," Journal of Urban History 27, no. 2 (January 2001): 158-177. In Japanese, see the works of Kim Eun-jin, Gotō Yasushi, and Hashiya Hiroshi. See also, Chon Woo-yong, "Shokuminchi toshi ime-ji to Bunka Genshō - 1920 nendai to Keijō," in Nikkan Rekishi Kyōdo- Kenkyü Hokokusho 3, jo-maki, ed. Nikkan Rekishi Kyōdō Kenkyū Iinkai (Tokyo: Nikkan Rekishi Kyō̄o-Kenkyü Iinkai, 2005), 207-235. 
and chronicled how Korean residents experienced the spaces of the new city. ${ }^{28}$ While building from this invaluable previous research, this article diverges from studies that view Japanese urban redevelopment programs primarily as efforts to facilitate exploitation of Korean resources through the construction of infrastructure, to project power and justify Japanese occupation of Korea through monumental structures and urban layouts, or to promote assimilation campaigns through the demonstration of Japanese modernity. Instead, this article re-reads the history of these programs to suggest that Japanese spatial strategies were informed by an additional settler colonial logic of claiming and sustaining Japanese seizure of Korean space, eliminating native Koreans from certain sections of the city.

The first section will review the well-documented history of Japanese street improvements in Seoul as attempts to, paraphrasing Veracini, make Korean places into unclaimed spaces, and then remake them as Japanese places where native Koreans were meant to be seen as, and feel, out of place. ${ }^{29}$ The second section then introduces the juridical structures Japanese colonizers erected in these spaces, in the form of building and street use codes, to enforce settler expectations of "civilization" in both built forms and public behavior. Together, street improvements and legal codes threatened to displace Korean residents by physically dismantling their homes to make way for widened roads, tearing down those structures that did not conform to new building standards, and criminalizing and removing residents who did not abide by settler ways of life. Through public works projects, Japanese colonizers sought to destroy and replace - to

28 Pai Hyung-Min, "Modernism, development, and the transformation of Seoul: a study of the development of Sae'oon Sang'ga and Yoido," in Culture and the City in East Asia, ed. Kim Won-Bae, et al. (Oxford: Clarendon Press, 2007), 104-124; Lee Kyu-Mok, "Transformation of Seoul's Modern Urban Landscape," in Seoul, Twentieth Century: Growth \& Change of the Last 100 Years, ed. Kwang-Joong Kim (Seoul: Seoul Development Institute, 2003), 91-150; and Hong Kal, "Seoul and the time in motion: urban form and political consciousness," Inter-Asia Cultural Studies 9, no. 3 (September 2008): 359-374.

29 Veracini, "Settler colonialism and a distinct mode of domination," 5. 
construct a visible difference between precolonial conditions and the colonial present through the destruction of the "primitive" and the introduction of "modernity." "It is said that if we are to build a new age here in Korea, then the present must be destroyed," wrote Tokyo Imperial University professor Kuroita Katsumi in 1922. "But even that destruction is done for the purpose of creation." 30

\section{Re-making Koreans as Out of Place through Street Improvements}

Settler colonial societies around the world from British Columbia to the Australian Outback looked out at "empty" frontier lands and declared them terra nullius, "unoccupied lands," awaiting civilized exploitation as a legal means to displace native inhabitants. Arriving in Korea, on the other hand, where the Yi Dynasty had ruled over a unified peninsula for over 500 years, Japanese colonizers were hard pressed to make a case for terra nullius. What they did instead was to argue that Korea's level of civilization was so low that Korean landscapes were in effect uncultivated. For Japanese officials in Korea, improvement of the existing terrain or environment entitled the cultivator to the rights and privileges of control, what Alexis Dudden has described as "enlightened exploitation." "Socalled civilized governments predicated their claims to legitimacy on conquering and ruling so-called barbaric ones," Dudden writes. "A regime was civilized only if it could claim the ability to transform an uncivilized people." 31 In the minds of Japanese officials and colonizers, then, improvement of natural and man-made environments through the construction of railways and public works projects would validate Japanese territorial claims. That is to say, Japanese leaders believed that "enlight-

30 Kuroita, "Bunka to Kenchiku," 3.

31 Alexis Dudden, Japan's Colonization of Korea: Discourse and Power (Honolulu: University of Hawai'i Press, 2005), 9. 
ened exploitation" of natural and man-made environments entitled the cultivator to ownership of territory and justified claims to rule. As colonial reports demonstrate, in the minds of Japanese officials, "development," "civilization," and governance were all closely related concepts, and all were dependent on public works projects, including urban improvements.

In Seoul, Japanese "enlightened exploitation" took the form of street improvement programs designed to transform the southern half of the city into settler colonial space even before the beginning of colonial rule. This resulted in the bifurcation of Seoul into a native northern half known as Pukch'on (Bukchon), and a settler southern half called Namch'on around the Japanese settlement. ${ }^{32}$ According to Jun Uchida, the settlement became "a mini-Tokyo that [settlers] christened Honmachi." ${ }^{33}$ On one hand, the goal of the improvements was to make Japanese residents feel more at home by introducing elements of the constructed environment and urban life familiar in the metropole. But, on the other, the projects had a second goal of making the southern half of the city "Japanese" in the conditions of the built environment, the economic practices and ways of life of the neighborhood, and in the ethnic makeup of the residents living there. For Japanese colonial planners, the man-made environment was the most visible mark of colonial difference. Streetscapes of straight, paved, and clean thoroughfares outfitted with sidewalks, sewers, and roadside trees would join with Western architecture to frame settler spaces that displaced native Koreans. While colonial officials and settler community leaders publicly professed a desire to uplift Korean civilization through infrastructural improvements, the unevenness of projects along with the promulgation of ordinances designed to prohibit Korean housing and ways of life, reveals concerted designs to eliminate native Koreans from settler spaces.

Construction of settler colonial spaces in Korea was not unique to Seoul, but was a common spatial strategy adopted by Japanese colonizers in cities around the peninsula, such as Pusan and Inch'ŏn. For example,

32 Kim, "Ruptures and Conflicts in the Colonial Power Bloc," 13.

33 Uchida, Brokers of Empire, 71. 
Park Chan-Seung has mapped the uneven development of the southwestern city of Mokp'o (Mokpo), calling it a "Dual City," "where living spaces were ethnically divided and the urban infrastructure differed greatly according to ethnic groups." ${ }^{34}$ Mokp'o, too, was divided into a northern native village and a southern settler village. As Park describes, the inequalities between the two halves of the city extended to the presence of most public facilities in the south, better physical conditions of housing and street surfaces in the south, more complete infrastructure like sewers, garbage disposal, and fresh water supply in the south, and even more streetlamps in the south. ${ }^{35}$ As Park concludes, the uneven development of dual cities was part of colonizers' attempts to "demonstrate their overwhelming power and publicize the legitimacy of domination under the name of "civilization." "36 Without a doubt, Japanese colonizers saw urban development as one means to project Japanese power and modernity in built form. Yet, we should also consider how Japanese programs were designed to make Koreans out of place.

Korean residents responded ambivalently to Japanese efforts to reshape Seoul and other urban centers. As Kim Baek-Yung has demonstrated, Korean residents "expressed strong discontent and hostility" towards Japanese destruction of historical sites and the construction of new public spaces, first privately and later publicly. ${ }^{37}$ Some travelled on backroads to avoid the gaze of the colonial state. ${ }^{38}$ Todd Henry, meanwhile, has persuasively shown how Korean residents used public space to "appropriate, deflect, or challenge the contradictory logics of Japanese rule," blocking Japanese attempts to install new roads or carry out land readjustment. ${ }^{39}$ Others saw the "colonial modernity" of the city as an opportunity

34 Park Chan-Seung, "Colonial Modernity and the Making of Mokpo as a Dual City," Korea Journal 48, no. 3 (Autumn 2008): 106.

35 Park, "Colonial Modernity and the Making of Mokpo," 123-126.

36 Park, "Colonial Modernity and the Making of Mokpo," 129.

37 Kim, "Ruptures and Conflicts in the Power Bloc," 9-10.

38 See: Kim, "Shokuminchi toshi Keijō no hiroba to roji," 21-31.

39 Henry, Assimilating Seoul 12, and especially Chapter 1. 
to rearticulate a new "collective identity of the Korean nation," as Hong Kal has argued. ${ }^{40}$ At the same time, the dual or split nature of the city caused other residents to feel conflicted or even alienated. "The new urban environment was conceived almost solely as an alien other," Hyungmin Pai notes. "This was a very specific form of alienation between the residents of the city and its built environment." 41 Still, scholars should be wary of reducing settler colonial strategies to a question of whether those strategies were "successful" or not. Regardless of outcome, it is important to articulate how Japanese settlers attempted to create settler colonial space, first by attempting to claim Koreans lands were uncultivated, then by obscuring the memory of improvement programs carried out by Korean reformers, and finally by physically demolishing the houses of Korean residents.

To justify public works programs across the peninsula, Japanese colonizers exaggerated the squalor of precolonial times, contending that Koreans had left the land so undeveloped as to make it effectively uncultivated. "Notwithstanding that public works must never be neglected even temporarily for the development of humanity and the promotion of industry," an official 1937 public works report declared, "the Korean government all but abandoned public works programs as a result of financial mismanagement and the rapid impoverishment of the country." 42 The report then reveals Japanese discursive attempts to claim that the Korean government had effectively surrendered its right to rule by failing to cultivate the land. "Roads were nothing more than rural pathways formed by the footprints of travelers; ports remained in their natural state, offering only the sound of crashing waves; rivers were left in their original conditions, overflowing and flooding with no end in sight; and cities were so

$40 \mathrm{Kal}$, "Seoul and time in motion," 361.

41 Pai, "Modernism, Development: Seoul," 114.

42 Chōsen Sōtokufu, ed., Chōsen Doboku Jigyōshi: Shōwa 3-nen made (Keijō: Chōsen Sōtokufu, 1937), 1. Accessed through the National Diet Library Digital Collections here: http://dl.ndl.go.jp/info:ndljp/pid/1875650. 
chaotic and disorganized as to be unhygienic." ${ }^{43}$ In this situation, where "there is no industrial advancement, no cultural progress, and national fortunes declined by the day," the report asserts, Japanese colonizers were left no choice but to initiate widescale public works programs around Korea, including road repairs, port construction, and river improvements starting in $1905 .^{44}$

Japanese planners especially exaggerated the disorder of Korea's "primitive" native cities. A 1922 Government-General report specifically called out Korea's "current low level of civilization (kaimei)" and the need for "comparatively rapid future development" as reasons for urban improvements. ${ }^{45}$ The Government-General later elaborated that street improvements were necessary because Korea was "still in the first stages of modernization in many ways" and "nothing [was] more keenly required" to "forward the sound development of a Korean town." 46 As the official history of public works projects in Korea recorded, "[In] the urban areas of Korea, as a rule, the streets are narrow and excessively winding, making the city blocks even more irregular; not only do they cause many hindrances in transportation, hygiene, and fire prevention, but they also cause many impediments in the development of the urban area." ${ }^{47}$ Likewise, the "great inconvenience to communications, and sanitary and fire-brigade arrangements" posed by the "narrow, dirty, and crooked streets" of Korean cities was a common theme in the GovernmentGeneral's Annual Reports. ${ }^{48}$

43 Chōsen Sōtokufu, ed., Chōsen Doboku Jigyōshi, 1.

44 Chōsen Sōtokufu, ed., Chōsen Doboku Jigyōshi, 1.

45 Chōsen Sōtokufu, ed., Chōsen Sōtokufu Shisei Nenpō 1922 (Seoul: Chōsen Sōtokufu, 1923), 305.

46 Government-General of Chosen, ed., Annual Report on Administration of Chosen, 1922-1923 (Keijo: Government-General of Chosen, 1924), 142-143; and Government-General of Chosen, ed., Annual Report on Administration of Chosen, 19241926 (Keijo: Government-General of Chosen, 1927), 140.

47 Chōsen Sōtokufu, ed., Chōsen Doboku Jigyōshi, 1023.

48 These and similar comments can be found in reports for 1918-1921, 1921-1922, 
Such rhetoric obscured the history of modernization efforts undertaken prior to the arrival of Japanese colonizers. In fact, the city had seen a series of projects that effected a remarkable change in its appearance long before the Japanese annexation of Korea in 1910. The famous world traveler Isabella Bird, for example, extolled the "extraordinary metamorphosis" she saw in the face of the city between her first trip to the city in 1894 and her return in 1896. "Seoul in many parts, specially in the direction of the south and west gates," Bird exclaimed, "was literally unrecognizable." Gone were the narrow alleyways and overflowing sewage ditches she had seen on her first visit. In their place were new streets "widened to 55 feet, with deep stone-lined channels on both sides, bridged by stone slabs." "Seoul," Bird concluded, "from having been the foulest is now on its way to being the cleanest city in the Far East!" 49 Bird attributed these improvements to the work of two people, British advisor to the Minister of Finance, John McLeavy Brown, and the governor of Seoul, Yi Ch'aeyŏn. Yi had visited Washington D.C. with the first Korean ambassador to the United States, Pak Chŏngyang, and this experience influenced his ideas for urban improvement. ${ }^{50}$

The street improvements in Seoul observed by Bird were part of a larger attempt by the Korean government to re-brand "the hermit kingdom" as the modern Great Han Empire (Taehan Cheguk), together with programs to construct railways across the peninsula. In the capital of Seoul, Todd Henry has described, the government cleared stalls impeding the city's main thoroughfares, installed new roads, and constructed several monu-

1922-1923, 1923-1924, 1924-1926, and 1929-1930. Quotes from GovernmentGeneral of Chosen, ed., Annual Report on Administration of Chosen, 1921-1922 (Keijo: Government-General of Chosen, 1923), 162.

49 Isabella Bird, Korea and Her Neighbors ([1897] London: KPI Limited, 1985), 40, 435-436. See Yi T'aejin, The Dynamics of Confucianism and Modernization in Korean History (Ithaca: Cornell University Press, 2007), 246-247, and Sohn Chŏng-Mok, "Colonial City Planning and Its Legacy," 434-435 for more discussion of Bird's recollections.

$50 \mathrm{Yi}$, The Dynamics of Confucianism and Modernization, 247, 270-271. 
ments in an attempt to "re-create the royal city of Hanyang into an 'imperial capital'." ${ }^{51}$ Yi T'aejin, likewise, has asserted that the street improvements observed by Bird in the mid-1890s were undertaken at the behest of King Kojong as part of a larger attempt to "make Seoul into a suitable imperial capital" for a newly independent Korea starting in mid-1896. ${ }^{52}$ According to Yi, King Kojong ordered the relocation of the court from Kyŏngbok Palace to Kyŏng'un Palace in early September 1896, and then initiated a massive urban redevelopment program centered on the new palace. ${ }^{53}$ Piecing together the admittedly limited historical record, Yi catalogues the improvements included in the plan as: 1) the laying or repair of roads and sewers, in addition to the clearing of new roads radiating from Kyŏng'un Palace; 2) the construction of new buildings, including Kyŏng'un Palace and Independence Gate; 3) the opening of new parks, such as Independence Park and Pagoda Park; 4) the introduction of electricity, waterworks, streetcars, and railways; and 5) the designation of an industrial district in Yongsan and a city market near Namdaemun. ${ }^{54} \mathrm{Yi}$ concludes that these projects "visibly changed the city's landscape," but during the colonial period, "The Japanese systematically obliterated the physical landmarks of the urban development that had been implemented by the emperor beginning in 1896, and the project itself was eventually forgotten." 55 Some scholars, such as planning historian Sohn ChŏngMok, on the other hand, have been skeptical of these arguments, pointing out "although highly feasible, no concrete proof has been found to prove what Kim and Lee [Yi] suggested." 56 What is certain, however, is that Japanese colonizers strategically downplayed Korean reform efforts in order to embellish the lack of planning in the capital and make a case for

51 Henry, "Respatializing Chosŏn's Royal Capital," 20.

$52 \mathrm{Yi}$, The Dynamics of Confucianism and Modernization, 269-273.

53 Yi, The Dynamics of Confucianism and Modernization, 249-250.

$54 \mathrm{Yi}$, The Dynamics of Confucianism and Modernization, 275-276.

55 Yi, The Dynamics of Confucianism and Modernization, 290-291.

56 Sohn, "Colonial City Planning and Its Legacy," 437. 
Japanese improvement programs. If this served to obscure the memory of Korean improvements, colonizers next turned to programs designed to physically drive Korean residents out of Japanese spaces. Here, the history of the Japanese settlement in Seoul is instructive.

Japanese efforts to displace Koreans from settler colonial spaces in Seoul started even before the beginning of formal colonial rule. As early as 1891, consulate official Sugimura Fukashi praised the "remarkable progress" seen in the Japanese areas of the southern part of the city, writing that the area around the consulate was starting to "take on the appearance of a Japanese village." 57 This was the product of Japanese expatriate residents, who had begun to reside in the city in large numbers from the early 1880s. At first, Japanese residents were confined to an area granted by the Korean government as the Japanese Settlement (kyoryūchi) on a hill at the foot of Mt. Namsan to the south. As the Japanese settlers quickly realized, this was not prime real estate. The area was known as " muddy town' (deiken or chinkōkai) ${ }^{58}$," Jun Uchida notes, and was "an area of relative neglect that had been inhabited by impoverished yangban elites and Chinese merchants in the Chosŏn period." 59 Sohn Chŏng-Mok likewise relates the origin of the name for the area, quoting $18^{\text {th }}$ century scholar Hong Ryangho: "It is a narrow low land, and when it rains the water does not drain well and the roads get muddy causing trouble for passers-by. That was why the village there is called Jingogae [chinkokae, or JPN: chinkokai] meaning 'a muddy hill." 60 Japanese residents grew

57 Japan Center for Asian Historical Records (JACAR): B12083364100, "Keijō Kyoryūchi Honpōnin Shoyū no Tochi narabini Kyoryūjin no tame Shōrai toru beki no Hōshin ni tsuki zai Keijō Ryōji gushin no ken," slide 2.

58 "Deiken" is the Japanese pronunciation of the two Korean Hanja characters for the name of the hill. In Korean, the characters can be pronounced either "Yihyŏn" or "Nihyŏn," while the official history of Keijō, published by the colonial government in 1936, gives the reading of these characters in Hangul as "Chinkokae (Jingogae).” See, Keijō-fu, ed., Keijō-fu Shi 2 (Keijō: Keijō-fu, 1936), 634.

59 Uchida, Brokers of Empire, 71.

60 Sohn, "Colonial City Planning and Its Legacy," 437. 
frustrated with the area because of its muddy conditions, its isolated location, and the fact that they were not allowed to open stores in other parts of Seoul. As the Japanese consul in Seoul, Sugimura Fukashi, complained to Tokyo in 1891, the settlement was "stuck into a corner of Seoul," which was bad for business. Chinese merchants, he noted by contrast, were free to open stores wherever they wanted in the city. It should be the policy of the Japanese government, Sugimura proposed, to ensure that Japanese merchants would have access to the central parts of Seoul, or risk the city becoming a "Chinese town" and Japanese and Korean residents together being forced out. ${ }^{61}$ Legation official Uchida Sadatsuchi later echoed these frustrations in 1896, complaining, "Deiken is a backwoods (hekichi) part of Seoul, located at the foot of Mt. Namsan. Its roads are so narrow and steep that it is exceedingly difficult for people or animals to pass, not to mention carts or wagons." 62

Unhappy with the poor conditions of the expatriate settlement, the Japanese consulate and residents in Seoul worked together to expand Japanese settler space beyond this muddy hill, removing Korean dwellings under the guise of street widening projects. The 1896 consular report from Uchida Sadatsuchi cited above details how the Japanese legation and the settler community co-opted building restrictions announced in April 1895 by the Korean government to displace Korean residents from both the Japanese settlement and surrounding neighborhoods Japanese settlers coveted. As new Japanese settlers arrived in Seoul after the SinoJapanese War, Uchida's report explains, more Japanese residents were starting to open stores in places such as Namdaemun, tearing down Korean houses to erect new Japanese-style structures. The Korean government

61 Sugimura's memo to Vice-Minister of Foreign Affairs Hayashi Tadasu, along with a map of Japanese holdings in settlement, can be found in JACAR: B12083364100, "Keijō Kyoryūchi Honpōnin Shoyū no Tochi narabini Kyoryūjin no tame Shōrai toru beki no Hōshin ni tsuki zai Keijō Ryōji gushin no ken."

62 Japan Center for Asian Historical Records (JACAR): B12083364500. "Deiken Chihō Dōro Shūri no Gi zai Keijō Uchida ryōji yori Hōkoku no ken Meiji Nijūkyūnen ni-gatsu," slide 4. 
opposed this, however, because the more permanent Japanese structures could not be removed to widen streets for processions by the Korean King Kojong. Uchida suggests that the Japanese consulate saw this order, instead, as a targeted attempt to ban Japanese construction outside the settlement. Still, Uchida relates, this presented an opportunity for the legation to expand the settlement from the "backwoods" corner of the settlement towards areas more convenient for transportation. With the approval of the Korean government, "all Korean-owned houses along the streets" leading from the settlement towards Ch'ŏnggye and Namdaemun were torn down after residents were given proper compensation. Within the settlement-proper, meanwhile, Korean-owned houses encroaching on the streets were all torn down in the name of widening roads. Since the Korean government funded the removal of Korean structures, Uchida boasted, "we got halfway to achieving our goal of widening the street, without any Japanese spending even one dollar." 63

With Korean dwellings cleared out of the settlement by May or June of 1895, Japanese consular officials and settlers carried out additional improvements designed to improve the district. First, the Japanese legation funded the digging of stone gutters on both sides of the street, the leveling of the road surface, and the application of new gravel paving. The Japanese Settlement Assembly (kyoryūchi minkai) - later called the Seoul Resident's Association (Keijō kyoryūchi mindan) - then determined plans for future road improvements and established a Road Improvement Committee to oversee their completion. To make the area more attractive to residents and shoppers alike, the association funded a garbage collection program, constructed gutters, repaved street surfaces in gravel, and installed street lamps. Projects were financed by Japanese landowners abutting the streets, while communal funds were used to pay for projects in front of houses owned by any remaining Korean residents. ${ }^{64}$ Several

63 JACAR: B12083364500, “Deiken Chihō Dōro Shūri no Gi zai Keijō Uchida ryōji yori Hōkoku no ken Meiji Nijūkyū-nen ni-gatsu," slides 5-6.

64 JACAR: B12083364500, “Deiken Chihō Dōro Shūri no Gi zai Keijō Uchida ryōji 
years later in 1901, the Assembly funded more street repairs in the settlement, at which point, according to a history of the Association, "the Settlement for the first time began to look like a Japanese village (machi)."

Earlier urban improvements in Seoul cooperatively carried out by the Japanese legation and settler communities set the stage for even more expansive projects following the annexation of Korea in 1910. Over the years from 1911 to 1937, Japanese colonial officials in the GovernmentGeneral and Keijō Municipal Government carried out no fewer than four concurrent street improvement programs. Altogether, officials in the Government-General and Keijō city government improved a total of 141 streets in the city, totaling just over 42 miles, of which 128 acres was paved, lined by 21 acres of paved sidewalks, and shaded by over 6,000 trees. ${ }^{66}$ When all was said and done, the Government-General boasted that street improvements "[brought] about an extraordinary change in both the appearance and traffic efficiency of the city," and "[added] one more step in the beautifying of the city and the convenience of traffic." 67 New street pavements, especially, were said to "[add] to the modern aspect of the city." ${ }^{68}$ Notably, projects carried out by the municipal government from 1917 to 1937 targeted streets in the northern half of the city as part of an attempt to enlarge the Japanese settlement zone. As one civil

yori Hōkoku no ken Meiji Nijūkyū-nen ni-gatsu," slides 7-8.

65 Keijō Kyoryūmin-dan Yakusho, ed., Keijō Hattatsu-shi (Keijō: Keijō Kyoryūmindan Yakusho, 1912; Tokyo: Ryūkei Shohsa, 2001), 75-76, 106. Citations refer to 2001 edition.

66 Keijō-fu, ed., Keijo-fu Doboku JigyōGaiyō: Shōwa 13-nen (Keijō: Keijō-fu: 1938), 14; Keijō-fu, ed., Keijo-fu Doboku Jigyo- Gaiyo-: Showa 10-nen 5-gatsu 15-nichi genzai (Keijō: Keijō-fu, 1935), 17 back-19 front, 20 back-21 back. Also available from the National Diet Library Digital Collection: http://dl.ndl.go.jp/info:ndljp/pid/ 3457529 .

67 Government-General of Chosen, ed., Annual Report 1923-1924, 135; and Government-General of Chosen, ed., Annual Report on Administration of Chosen, 1929-1930 (Keijo: Government-General of Chosen, 1931), 118.

68 Government-General of Chosen, ed., Annual Report 1924-1926, 140. 
engineering report explained, "because these construction projects carry out sectional improvements in the especially unregulated backstreets of the old urban area, the results are remarkable." ${ }^{9}$ To be sure, as Jun Uchida and Kim Baek-Yung have shown, the colonial state and settler communities did not always agree on these programs. For example, as Government-General improvement programs after the 1920s focused on the northern areas of the city, the Japanese settler community based in Namch'on felt abandoned and agitated for further development around Mt. Namsan and the Han River. ${ }^{70}$ In this way, even though they did not always unquestioningly support Government-General programs, settler goals still aligned with those of the colonial state. But street improvement programs were just one aspect of constructing settler colonial space. Japanese colonizers also enforced building restrictions and street use codes intended to regulate public behavior according to Japanese notions of decency, and to make Koreans feel out of place within the colonial city.

\section{Regulating Spaces of Settler Behavior}

Japanese attempts to construct settler colonial space in Seoul extended from the physical structure of streets into urban space through a number of regulations on building construction and street use. With these codes, colonizers sought to legislate adherence to Japanese expectations of "civilized" life within Japanese modern settler colonial spaces and to displace Korean residents by marking them "out of time and out of space."71

Japanese colonizers promulgated the Urban Area Construction Control Codes (shigaichi kenchiku torishimari kisoku) in $1913 .{ }^{72}$ Enacted across

69 Keijō-fu, ed., Keijō-fu Doboku Jigyō Gaiyō (1935), 13 back.

$70 \mathrm{Kim}$, "Ruptures and Conflicts in the Colonial Power Bloc," 15-16.

71 Edmonds, "Unpacking Settler Colonialism's Urban Strategies," 8.

72 Chōsen Sōtokufu, Chōsen Sōtokufu Furei \#11, "Shigaichi Tatemono Torishimari Kisoku hidari no tōri sadamu," in Kanpo-\#174. March 1, 1913. Accessed through 
the city of Seoul, the codes announced standards for fireproof construction and sanitation. For example, the codes provided detailed instructions for fireproofing chimneys (Article 3) and required the installation of nonflammable roofing and lightning rods for buildings over 50 feet tall (Article 4). Rowhouses (nagaya) constructed of wood, moreover, were required to have firewalls every 120 feet (Article 4). Sanitary restrictions, meanwhile, were directed outwards towards neighbors rather than inwards to living quarters. Five of the 21 provisions in the codes addressed sanitation, yet only two dealt with the interior of the house: requirements for "proper sewage and water systems" and toilets (Article 3). Other hygiene related provisions mainly concerned the appearance and health of the neighborhood as a whole: stipulations that drinking wells must be separated from excrement pits, sewage pits, and ditches by at least 18 feet, that excrement pits must be constructed in non-permeable materials (Article 3), and that public toilets should not be installed on public roads unless enclosed by privacy walls (Article 4). ${ }^{73}$ Finally, owners of large buildings were encouraged to take "all possible measures" to prevent rat infestation, and buildings that stored or handled goods that emitted "bad odors, noxious fumes, or dust" were not allowed to have any windows or doors facing public roads, buildings where large numbers of people would gather, or neighboring residences (Article 3). In effect, the codes enforced Japanese notions of "civilized" neighborhood construction. Following the announcement of the law, all new construction, reconstruction, or repair of buildings and roadside structures were subject to the approval of the police. The police also reserved the right to ban or halt the construction of any building not up to code. Owners of buildings not up to code faced a fine up to $¥ 100$. At the time, colonial laborers could expect wages of $¥ 1.5$ to $¥ 2$ a day in Korea. ${ }^{74}$

the National Diet Library Digital Collections: http://dl.ndl.go.jp/info:ndljp/pid/295 2272.

73 Chōsen Sōtokufu, Chōsen Sōtokufu Furei \#11.

74 Information on wages from Mizoguchi Toshiyuki, "Consumer Prices and Real 
Japanese attempts to discipline the population did not stop at the front door; rather building codes went hand in hand with street use regulations in attempts to frame life and condition popular behavior both indoors and out. The colonized populace was expected to conform to Japanese dictates of home life by self-reporting and making certain all new construction, remodeling, or additions were up to code at the risk fines in Korea for failure to report, lack of compliance, or for submitting false information. To make things worse, the colonized population was also required to comport itself according to Japanese prescriptions of "civilized" public behavior once they left the house. This was especially true in Korea, where street use codes were issued as early as 1913. As Todd Henry has argued, Japanese-led projects to sanitize Seoul and reform the public hygienic practices of the Korean population were major components of Japan's strategy of colonial rule. The colonial government forced both Korean and Japanese residents to pay a monthly service fee to support the garbage collection, sewage disposal, and general urban sanitation efforts of the Japanese-founded Seoul Sanitary Association. ${ }^{75}$ It should be added, however, that the colonial government attempted to discipline public behavior in the form of these regulations on street use. In this way, colonial power extended not only to the constructed form of the house, but also to the body of the individual in the street.

Japanese colonizers also issued street use codes in Korea designed to enforce "modern" standards of hygiene and public decency on the streets. As part of colonial efforts to sanitize the city and improve urban appearance, the 1913 Road Control Codes (dōro torishimari kisoku) in Korea added strict standards for public decency and discipline. ${ }^{76}$ Concerned

Wages in Taiwan and Korea Under Japanese Rule," Hitotsubashi Journal of Economics 13, no. 1 (June 1972): 56.

75 Henry, "Sanitizing Empire," 656.

76 Chōsen Sōtokufu, Chōsen Sōtokufu Furei \#53, "Dōro Torishimari Kisoku hidari no tōri sadamu," in Kanpō \#252, June 3, 1913. Accessed through the National Diet Library Digital Collection: https://dl.ndl.go.jp/info:ndljp/pid/2952350. 
about hygiene and public image, codes forbade letting cows or horses offleash, outlawed dumping or scattering refuse, sewage, or nightsoil into the street, and prohibited the transportation of nightsoil containers without appropriate lids. Other codes specifically targeted public indecency and disruptive behaviors. In Seoul, the display on or near the street of any advertisement or sign that "disturbs public safety or manners (kōan moshikuha füzoku wo midari)" was strictly forbidden (Article 19). Article 20, meanwhile, criminalized playing (yügi) in the street, loud singing ( $h \bar{o} k a$ ), or excessively loud voices (takagoe) after being ordered to stop by the police or military. Anyone who failed to comply with these restrictions was subject to detention by the police or a fine. Modern streets, the colonial government seemed to be saying, required modern public behavior.

Together, building and street use codes formed a juridical arsenal designed to enframe Japanese settler space and enforce Japanese expectations of civilized behavior onto the Korean residents of Seoul. This was part of broader Japanese attempts to replace native Korean customs with Japanese practices, forms, and language. Efforts to reshape daily life extended to the side of the road vehicles used. Originally, the 1913 street use codes followed the then-current practice of travelling on the right side of the street, stipulating that pedestrians should walk on the right edge, while oxen, horses, and various vehicles were to travel on the right side of the central area (Article 7). In a dramatic reversal, the GovernmentGeneral declared on October $25^{\text {th }}, 1921$, that from December $1^{\text {st }}$ of that year, traffic directions would be reversed to match those in the metropole: traffic would now flow on the left side of the street rather than the right. ${ }^{77}$ Korean residents who refused to abide by Japanese settler expectations of space now not only risked fines or jailing, but rushing headlong into on-

77 Chōsen Sōtokufu, Chōsen Sōtokufu Furei \#142, "Dōro Torishimari Kisoku-jū hidari no tōi kaisei-su," in Kanpō \#2779, November 5, 1921. Accessed through the National Diet Library Digital Collection: http://dl.ndl.go.jp/info:ndljp/pid/2954 894. 
coming traffic.

\section{Conclusion: Public Works and Japanese Settler Space}

This article has attempted to show how scholars can draw on settler colonial studies to offer new perspectives on Japanese colonial rule in Korea. It argued that Japanese colonial officials and settler residents cooperatively carried out public works projects designed to construct settler spaces that would assert Japanese claims to territory and displace native Korean inhabitants and their customs towards the goal of perpetuating Japanese presence in Korea. In Seoul, this meant tearing down Korean structures in the name of street widening, along with issuing building regulations and street use codes in the name of public safety that otherwise enforced "civilized" forms and public behavior while eliminating those considered "primitive" in Japanese eyes.

Re-reading well-documented historical topics through a new analytical lens inevitably raises questions of what new insights such an exercise contributes to previous understandings of the topic in question. This article suggests that the logic animating public works programs in Korea was not limited to material or strategic colonial goals. To be sure, public works had several materials benefits for Japanese colonizers. Especially in the colonial countryside, improvements to roads, railways, ports, and rivers, along with cadastral surveys, were designed to make colonialism profitable by facilitating the exploitation of the colonial landscape to the benefit of the metropole as agricultural, industrial, and commercial goods were shipped back to Japan. Transportation improvements had the added logistical advantage of expediting troop movements, both to pacify local insurrection and to dispatch armies in time of war. Colonial public works also advanced the conceptual goal of legitimating Japanese colonialism, as Japanese rulers saw development as a means of validating Japanese claims to territorial ownership and affirming Japan's right to rule. By cultivating land that earlier governors had failed to exploit, pacifying territo- 
ry that the previous regime had been unable to rule, and sanitizing and ordering cities their predecessors had left unorganized, Japanese rulers thought they could legitimize colonial rule.

Yet, reconsidering Japanese urban development in colonial Seoul through the perspective of settler colonialism reminds scholars to consider the possibility that an additional logic informed public works programs: that Japanese colonizers and settlers carried out programs simply because they intended to stay. Thinking along these lines, we can see how infrastructure and housing improvements were carried out to make Japanese colonial officials and expatriate residents feel "at home" by re-creating "Japan Towns" within the city, such as Seoul's "Honmachi," even as they displaced Korean residents from theirs. Not surprisingly, efforts to produce modern streetscapes - the paving of streets, the digging of gutters, the laying of water and sewer systems, the planting of trees, the installation of street lamps and sidewalks, the construction of fireproof housing and Western-style buildings - were localized to areas of Japanese residence. Various development projects around the peninsula documented in the Annual Reports, including construction of railways, roads, and ports, along with agricultural improvements programs, can all be understood as efforts to advance the economic interests of the Japanese settler population in Korea as much as metropolitan ones. Why, then, did Japanese colonizers spend so much energy and money carrying out public works in Korea? The settler colonial framework suggests that the answer was not simply to exploit Korean resources, or to justify Japanese colonial rule, or to promote assimilation. Instead, it was because they had more selfish interests in mind, namely perpetuating Japanese control of Korean space. In other words, to stay.

\section{References}

1. Agrawal, Arun. Environmentality: Technologies of Government and the Making of Subjects. Durham, NC: Duke University Press, 2005. 
2. Anker, Peder. Imperial Ecology: Environmental Order in the British Empire 1895-1945. Cambridge: Harvard University Press, 2001.

3. Azuma, Eiichiro. In Search of Our Frontier: Japanese America and Settler Colonialism in the Construction of Japan's Borderless Empire. Berkeley: University of California Press, 2019.

4. Beinart, William, \& Lotte Hughes, ed. Environment and Empire. Oxford University Press, 2007.

5. Bird, Isabella. Korea and Her Neighbors. [1897] London: KPI Limited, 1985.

6. Carroll, Clint. "Commentary: The Environmental Anthropology of Settler Colonialism, Part II," Engagement. https://aesengagement.wor dpress.com/2017/05/16/commentary-the-environmental-anthropology -of-settler-colonialism-part-ii/.

7. Chon, Woo-Yong. "Shokuminchi toshi ime-ji to Bunka Genshō-1920 nendai to Keijō." In Nikkan Rekishi Kyodo- Kenkyü Hokokusho 3, jomaki, edited by Nikkan Rekishi Kyōdō Kenkyū Iinkai, 207-235. Tokyo: Nikkan Rekishi Kyödo- KenkyüIinkai, 2005.

8. Chōsen Sōtokufu. Chōsen Sōtokufu Furei \#11. "Shigaichi Tatemono Torishimari Kisoku hidari no tōri sadamu." In Kanpo-\#174. March 1, 1913. Accessed through the National Diet Library Digital Collections: http://dl.ndl.go.jp/info:ndljp/pid/2952272.

9. Chōsen Sōtokufu. Chōsen Sōtokufu Furei \#53. "Dōro Torishimari Kisoku hidari no tōri sadamu." In Kanpō \#252. June 3, 1913. Accessed through the National Diet Library Digital Collection: https://dl.ndl.go.jp/info:ndljp/pid/2952350.

10. Chōsen Sōtokufu. Chōsen Sōtokufu Furei \#142. "Dōro Torishimari Kisoku-jū hidari no tōri kaisei-su." In Kanpō \#2779. November 5, 1921. Accessed through the National Diet Library Digital Collection: http://dl.ndl.go.jp/info:ndljp/pid/2954894.

11. Chōsen Sōtokufu, ed. Chōsen Sōtokufu Shisei Nenpō 1922. Seoul: Chōsen Sōtokufu, 1923.

12. Chōsen Sōtokufu, ed. Chōsen Doboku Jigyōshi: Shōwa 3-nen made. Keijō: Chōsen Sōtokufu, 1937. Accessed through the National Diet 
Library Digital Collections here: http://dl.ndl.go.jp/info:ndljp/pid/187 5650.

13. Christy, Alan S. "The Making of Imperial Subjects in Okinawa." positions 1, no. 3 (1993): 607-639.

14. Crosby, Alfred. Ecological Imperialism: The Biological Expansion of Europe, 900-1900. Cambridge University Press, 1986.

15. Dudden, Alexis. Japan's Colonization of Korea: Discourse and Power. Honolulu: University of Hawai'i Press, 2005.

16. Edmonds, Penelope. “Unpacking Settler Colonialism's Urban Strategies: Indigenous Peoples in Victoria, British Columbia, and the Transition to a Settler-Colonial City." Urban History Review 38, no. 2 (March 2010): 4-20.

17. Government-General of Chosen, ed. Annual Report on Administration of Chosen, 1921-1922. Keijo: Government-General of Chosen, 1923.

18. Government-General of Chosen, ed. Annual Report on Administration of Chosen, 1922-1923. Keijo: Government-General of Chosen, 1924.

19. Government-General of Chosen, ed. Annual Report on Administration of Chosen, 1924-1926. Keijo: Government-General of Chosen, 1927.

20. Government-General of Chosen, ed. Annual Report on Administration of Chosen, 1929-1930. Keijo: Government-General of Chosen, 1931.

21. Grunow, Tristan R., Fuyubi Nakamura, Katsuya Hirano, Mai Ishihara, ann-elise lewallen, Sheryl Lightfoot, Mayunkiki, Danika MedakSaltzman, Terri-Lynn Williams-Davidson, and Tomoe Yahata. "Hokkaidō 150: settler colonialism and Indigeneity in modern Japan and beyond." Critical Asian Studies 51, no. 4 (December 2019): $597-$ 636.

22. Henry, Todd A. Assimilating Seoul: Japanese Rule and the Politics of Public Space in Colonial Korea, 1910-1945. Berkeley: University of California Press, 2014. 
23. Henry, Todd A. "Sanitizing Empire: Japanese Articulations of Korean Otherness and the Construction of Early Colonial Seoul, 1905-1919." The Journal of Asian Studies 64, no. 3 (August, 2005): 649-675;

24. Henry, Todd A. "Respatializing Chosŏn's Royal Capital: The Politics of Japanese Urban Reforms in Early Colonial Seoul, 1905-1919.” In Sitings: Critical Approaches to Korean Geography, edited by Timothy Tangherlini and Sallie Yea, 15-38. Honolulu: University of Hawai'i Press, 2007.

25. Howell, David. "Making 'Useful Citizens' of Ainu Subjects in Early Twentieth-Century Japan." The Journal of Asian Studies 63, no. 1 (February 2004): 5-29.

26. Hugill, David. "What is a settler-colonial city?" Geography Compass 11, no. 5 (May 2017). https://doi.org/10.1111/gec3.12315.

27. Japan Center for Asian Historical Records (JACAR): B12083364100. "Keijō Kyoryūchi Honpōnin Shoyū no Tochi narabini Kyoryūjin no tame Shōrai toru beki no Hōshin ni tsuki zai Keijō Ryōji gushin no ken."

28. Japan Center for Asian Historical Records (JACAR): B12083364500. "Deiken Chihō Dōro Shūri no Gi zai Keijō Uchida ryōji yori Hōkoku no ken Meiji Nijūkyū-nen ni-gatsu."

29. Jeong, Won-Sik. "The Urban Development Politics of Seoul as a Colonial City.” Journal of Urban History 27, no. 2 (January 2001): 158-177.

30. Kal, Hong. "Seoul and the time in motion: urban form and political consciousness." Inter-Asia Cultural Studies 9, no. 3 (September 2008): 359-374.

31. Keijō-fu, ed. Keijo-fu Doboku Jigyo- Gaiyo- Showa 10-nen 5-gatsu 15-nichi genzai. Keijō: Keijo-fu, 1935. Also available from the National Diet Library Digital Collection: http://dl.ndl.go.jp/info:ndlj $\mathrm{p} / \mathrm{pid} / 3457529$.

32. Keijō-fu, ed. Keijō-fu Shi 2. Keijō: Keijō-fu, 1936.

33. Keijō-fu, ed. Keijo-fu Doboku Jigyo- Gaiyo-: Shōwa 13-nen. Keijō: Keijō-fu: 1938. 
34. Keijō Kyoryūmin-dan Yakusho, ed. Keijō Hattatsu-shi. Keijō: Keijō Kyoryūmin-dan Yakusho, 1912; Tokyo: Ryūkei Shohsa, 2001. Citations refer to 2001 edition.

35. Kim, Baek-Yung. "Ruptures and Conflicts in the Colonial Power Bloc: The Great Keijo Plan of the 1920s." Korea Journal 48 (August 2008): 10-40.

36. Kim, Baek-Yung, "Shokuminchi toshi Keijō no hiroba to roji." In Shokuminchi Chōsen to Teikoku Nihon: Minzoku, Toshi, Bunka, edited by Suh Johng Wan and Masuo Shinichirō, 21-31. Tokyo: Bensei Shuppan, 2010.

37. King, Anthony D. Colonial Urban Development: Culture, Social Power, and Environment. Boston: Routledge, 1976.

38. Kuroita, Katsumi. "Bunka to Kenchiku." Chōsen to Kenchiku 1, no. 2 (February 1922): 2-10.

39. Lee, Hong-Yung. "Introduction: A Critique of 'Colonial Modernity'." In Colonial Rule and Social Change in Korea, 1910-1945, edited by Lee Hong-Yung, Yong Chool Ha, and Clark W. Sorensen, 3-38. Seattle: University of Washington Press, 2013.

40. Lee, Kyu-Mok. "Transformation of Seoul's Modern Urban Landscape." In Seoul, Twentieth Century: Growth \& Change of the Last 100 Years, edited by Kwang-Joong Kim, 91-150. Seoul: Seoul Development Institute, 2003.

41. Li, Tania Murray. The Will to Improve: Governmentality, Development, and the Practice of Politics. Durham, NC: Duke University Press, 2007.

42. Lu, Sidney Xu. The Making of Japanese Settler Colonialism: Malthusianism and Trans-Pacific Migration, 1868-1961. Cambridge: Cambridge University Press, 2019.

43. Lynn, Hyung-Gu. "Malthusian Dreams, Colonial Imaginary: The Oriental Development Company and Japanese Emigration to Korea." In Settler Colonialism in the Twentieth Century, edited by Caroline Elkins and Susan Pedersen, 25-40. New York: Routledge, 2005.

44. Mar, Tracey Banivanua, and Penelope Edmonds. "Introduction: 
Making Space in Settler Colonies." In Making Settler Colonial Space: Perspectives on Race, Place and Identity, edited by Tracey Banivanua Mar and Penelope Edmonds, 1-24. New York: Palgrave Macmillan, 2010.

45. Mar, Tracey Banivanua, and Penelope Edmonds, ed. Making Settler Colonial Space: Perspectives on Race, Place and Identity. New York: Palgrave Macmillan, 2010.

46. Mason, Michele M. Dominant Narratives of Colonial Hokkaido and Imperial Japan: Envisioning the Periphery and the Modern NationState. New York: Palgrave Macmillan, 2012.

47. Mizoguchi, Toshiyuki. "Consumer Prices and Real Wages in Taiwan and Korea Under Japanese Rule.” Hitotsubashi Journal of Economics 13, no. 1 (June 1972): 40-56.

48. Njoh, Ambe J. Planning Power: Town Planning and Social Control in Colonial Africa. New York: UCL, 2006.

49. Oguma. Eiji. The Boundaries of "the Japanese." Melbourne: Trans Pacific Press, 2014.

50. O’Neill, Karen M. Rivers by Design: State Power and the Origins of US Flood Control. Durham, NC: Duke University Press, 2006.

51. Pai, Hyung-Min. "Modernism, development, and the transformation of Seoul: a study of the development of Sae'oon Sang'ga and Yoido." In Culture and the City in East Asia, edited by Kim Won-Bae, Mike Douglas, Sang-Chuel Choe, and Kong Chong Ho, 104-124. Oxford: Clarendon Press, 2007.

52. Park, Chan-Seung. "Colonial Modernity and the Making of Mokpo as a Dual City." Korea Journal 48, no. 3 (Autumn 2008): 106.

53. Porter, Libby, and Oren Yiftachel. "Urbanizing Settler-Colonial Studies: Introduction to the Special Issue." Settler Colonial Studies 9, no. 2 (2019): 177-186.

54. Radding, Cynthia. Landscapes of Power and Identity: Comparative Histories in the Sonoran Desert and the Forests of Amazonia from Colony to Republic. Durham, NC: Duke University Press, 2005.

55. Sharma, Jayeeta. Empire's Garden: Assam and the Making of India. 
Durham, NC: Duke University Press, 2011.

56. Sohn, Chŏng-Mok. "Colonial City Planning and Its Legacy." In Seoul, Twentieth Century: Growth \& Change of the Last 100 Years, edited by Kim Kwang-Joong, 489-542. Seoul: Seoul Development Institute, 2003.

57. Tomiak, Julie. "Contesting the Settler City: Indigenous SelfDetermination, New Urban Reserves, and the Neoliberalization of Colonialism." Antipode 49, no. 4 (2017): 928-945.

58. Tucker, Richard P. Insatiable Appetite: The United States and the Ecological Degradation of the Tropical World. Berkeley: University of California Press, 2000.

59. Uchida, Jun. Brokers of Empire: Japanese Settler Colonialism in Korea, 1876-1945. Cambridge: Harvard University Asia Center, 2011.

60. Veracini, Lorenzo, “'Settler Colonialism': Career of a Concept." The Journal of Imperial and Commonwealth History 41, no. 2 (2013): 313-333.

61. Veracini, Lorenzo. "Settler colonialism as a distinct mode of domination." In The Routledge Handbook of the History of Settler Colonialism, edited by Edward Cavanaugh and Lorenzo Veracini, 1-8. New York: Routledge, 2016.

62. Wolfe, Patrick. "Settler colonialism and the elimination of the native." Journal of Genocide Research 8, no. 4 (December 2006): 387-409.

63. Wright, Gwendolyn. The Politics of Design in French Colonial Urbanism. Chicago: The University of Chicago Press, 1991.

64. Yeoh, Brenda S.A. Contesting Space: Power Relations and the Urban Built Environment in Colonial Singapore. New York: Oxford University Press, 1996.

65. Yi, T'ae-jin. The Dynamics of Confucianism and Modernization in Korean History. Ithaca: Cornell University Press, 2007. 


\section{Cultivating Settler Colonial Space in Korea: Public Works and the Urban Environment under Japanese Rule}

Tristan R. Grunow(Yale University)

This article makes a case for reviewing Japanese colonial rule in Korea through the lens of settler colonialism, arguing that Japanese settlers and colonial officials used public works projects to reshape Korean landscapes into settler colonial spaces in the name of cultivating Japanese claims to ownership of Korean territory and displacing Korean inhabitants. Together, street improvements and legal codes were designed to displace Korean residents by physically dismantling their homes to make way for widened roads, tearing down those structures that did not conform to new building standards, and removing residents who did not abide by settler ways of life. Reconsidering Japanese urban development in colonial Seoul through settler colonialism suggests that Japanese public works projects were intended not only to exploit Korean resources, justify Japanese colonial rule, or promote assimilation, but to perpetuate Japanese control of Korean space.

Keywords: settler colonialism, urban space, public works, street improvement 
<국문초록>

\section{정착형 식민주의의 지배 공간 조성: \\ 일본 통치 하 경성의 토목사업과 도시환경}

Tristan R. Grunow (Yale University)

이 논문은 정착형 식민주의(settler colonialism)의 관점에서 일본의 조선 식민 지 통치를 재고찰한다. 일본인 개척자와 통치자는 토목 사업을 통해 조선 반 도의 재개발을 계획함과 동시에, 일본인 개척자의 조선 영토 점유 권리를 확 립해 나가면서 한국인 거주민을 배제하려고 시도한 것이라고 이해된다. 또한 도로 개량 사업에 착수하여, 건축기준, 도로단속규칙 등 도시 공간의 구조 기 술을 고안하여, 법률에 따르지 않는 한국인 가옥이나 거주인을 경성 내 일본 인 통치자의 구역인 “혼마치”에서 몰아냄으로써 통치 영역 공간을 창작하려 고 했다. 정착형 식민주의 이론의 관점에서 보면, 일제 통치하 경성에서의 토 목 사업은 통치 권리와 동화 정책의 버팀목이 되는 개발 수단이었을 뿐만 아 니라, 일본 개척자의 통치 영역 공간을 성립하기 위한 의도였다는 것을 분명 히 알 수 있다.

주제어: 정착형 식민주의, 도시 공간, 토목 사업, 도로 개량 
<日文抄錄>

\section{殖民 - 植民の支配空間構造: 日本統治下京城における土木事業と都市環境}

Tristan R. Grunow (Yale University)

この論文は、殖民・植民地主義理論(settler colonialism)の視点から日本の朝鮮植民 地統治の再考察を行う。日本人の開拓者や統治者は土木事業による朝鮮半島の再開 発を計画するに伴い、日本人開拓者の韓国における領土占有の権利を確立しなから韓 国人の居住人の排除を試みたのたと読み取れる。なお、道路改良事業を初め、建築基 準や道路取締規則なとの都市空間構造の技術を操作し、日本人統治者は京城市内の 「本町」から法律に準拠しない韓国人家屋や居住人を取り除くことによって、統治領域空 間を創作しようとしたと考えられる。殖民・植民地主義理論の視点から見ると、日本統治 下京城における土木事業は統治権利や同化政策を支える朝鮮半島の開発のために行わ れたというたげてな゙く、日本開拓者の統治領域空間の成立を意図するものたったということ は明らかてある。

キーワード: 殖民·殖民地主義、都市空間、土木事業、道路改良 
